\title{
Stage II Vaginal Cancer AJCC v6 and v7
}

National Cancer Institute

\section{Source}

National Cancer Institute. Stage // Vaginal Cancer A/CC v6 and v7. NCI Thesaurus. Code C7857.

Stage II includes: T2, N0, M0.T2: Tumor invades paravaginal tissues but not to pelvic wall. N0: No regional lymph node metastasis. MO: No distant metastasis. (AJCC 6th and 7th eds.) 